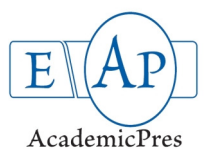

\title{
Leaf and Fruit Yield Performance of Telfairia occidentalis Hook F. (Fluted Pumpkin) as Influenced by Fruit Size
}

\author{
Uchechukwu P. CHUKWUDI*, Christian U. AGBO
}

\author{
University of Nigeria, Faculty of Agriculture, Department of Crop Science, Nsukka, Nigeria; c_agbogenetics@yahoo.com; \\ uchechukwu.chukwudi@unn.edu.ng (*corresponding author)
}

\begin{abstract}
An experiment to ascertain the influence of fruit size on the yield of fluted pumpkin (Telfairia occidentalis Hook F.) was conducted in 2011 and 2012 at Nsukka. The mature fruits of T. occidentalis were graded into three length groups: large (more than $50 \mathrm{~cm}$ ), medium (34$50 \mathrm{~cm}$ ) and small (less than $34 \mathrm{~cm}$ ). The experiment was laid out in randomized complete block design with six replications. The following data were collected: length of the longest vine, number of leaves/plant, vine diameter, marketable leaf and fruit yield. Data collected were subjected to analysis of variance while Genotype by Genotype x Environment interaction biplot was used to show which-won-where among the groups. Significant means were separated using Fisher's least significant differences. Medium sized fruits gave the highest marketable leaf yield that was significantly higher than the small sized fruits in both years. Small sized fruits were significantly $(\mathrm{p}<0.05)$ lower in total leaf yield, fruit weight/hectare, fruit circumference $(33.9 \mathrm{~cm})$ and length $(22 \mathrm{~cm})$. The biplot explained $100 \%$ of the variation in the fruit sizes. Large sized fruits were the best performer in fruit length, while medium sized fruits performed better in total marketable leaf yield, average fruit weight, number of fruits/hectare and total fruit weight/hectare. The highest Benefit Cost Ratio of 1.2 and 2.6 in 2011 and 2012, respectively were obtained from medium sized fruits Medium sized fruit are recommended in favour of small sized fruit for leaf and fruit production, having higher economic returns.
\end{abstract}

Keywords: cost-benefit ratio, fruit size, growth, telfairia, yield

\section{Introduction}

Fluted pumpkin (Telfairia occidentalis Hook F.) is an important vegetable supplement in the carbohydrate dominated staple food chain of West Africa, particularly Nigeria. Fluted pumpkin is a rich source of protein, oil, vitamins and minerals (Aregheore, 2007) and had been proposed to have some medicinal values (Kayode and Kayode, 2011). The tender vines, leaves and seeds are consumed by humans, while the mature vines constitute an important fiber source in animal diet.

Nkang et al. (2000) observed that in about 3-4 months, the fruit pulp undergoes decomposition with the seeds germinating in it. This recalcitrant and viviparous nature of the seeds hinders its long storage (Ajayi et al., 2006) hence, the continuous loss of farmers selections from their farm. This had necessitated a continuous selection/purchase of fruit from the field/market by the farmers for each planting season. Odiaka et al. (2008) reported that Makurdi farmers believed that fruits sourced from southeastern parts of Nigeria are of higher yielding qualities than those obtained from Makurdi, hence the preference of fruits from Isi-Ukwuato, Uturu and Nsukka in Abia, Imo and Enugu States, respectively. This preference of a particular seed source underscores the importance of seed quality in field establishment and yield estimation as seeds contains the genetic code that is expressed under favourable conditions.
Research findings had indicated that some production techniques can be used to improve the yield of fluted pumpkin. These include time of planting (Asiegbu, 1985), tillage practice (Awodun, 2007b) cutting frequency (Chukwudi and Agbo, 2013; Ogar and Asiegbu, 2005), manure rate (Awodun, 2007a; Ogar and Asiegbu, 2005) and staking (Chukwudi and Agbo, 2013; Egun, 2007). Germplasm evaluation had also been used in the identification of some morphological traits that will guide farmers in the selection of high yielding genotypes.

Odiaka et al. (2008) identified seed size (physiological quality), thickness of fruit ridge, size of the fruit, leaf size, leaf area and the thickness of vine (genetic quality) as distinguishing characters in fluted pumpkin. Variation in fruit sizes (Adeyemo and Odiaka, 2004; Akanbi et al. 2007; Chukwudi and Agbo, 2014a) and shapes (Ogbonna, 2008) of fluted pumpkin had been reported, but with little or no emphasis on how it affects the growth and yield of fluted pumpkin. The transition of fluted pumpkin from backyard to commercial crop entails that Telfairia farmers need to maximize profit in order to sustain production. Nwauwa and Omonona (2010) suggested that for fluted pumpkin to play a vital role in ensuring future food availability for food security and nutrition in the country, its production has to develop and expand in an economically viable and environmentally sustainable manner. 
510

Due to the viviparous and recalcitrant nature of fluted pumpkin seeds, producers hardly open the fruit to display the seeds to buyers. Hence, farmers often pay premium price for the large sized fruits with the hope of getting a higher leaf and fruit yield from them. There is dearth of information on the influence of fruit size on the growth, leaf and fruit yield of fluted pumpkin, hence the study was carried out to quantify leaf and fruit yields of $T$. occidentalis based on fruit sizes.

\section{Materials and methods}

Field experiments were conducted at the Department of Crop Science Teaching and Research Farm, Faculty of Agriculture, University of Nigeria, Nsukka ( $07^{\circ} 29^{\prime} \mathrm{N}, 06^{\circ} 51^{\prime}$ $\mathrm{E}$ and 400 m.a.s.l.) in 2011 and 2012. The mature fruits of $T$. occidentalis were purchased from the market and graded into three length groups: large (more than $50 \mathrm{~cm}$ ), medium (34$50 \mathrm{~cm}$ ) and small (less than $34 \mathrm{~cm}$ ) (Fig. 1). The experiment was laid out in randomized complete block design (RCBD) with six replications. The experimental field of $320 \mathrm{~m}^{2}$ was cleared, ploughed, harrowed and marked out into six blocks to increase precision. Each block was divided into three plots measuring $4 \times 3 \mathrm{~m}\left(12 \mathrm{~m}^{2}\right)$. A distance of $1 \mathrm{~m}$ was allowed between and within blocks. Germination study was carried out on the different fruit sizes in the nursery. The pre-sprouted seeds were transplanted randomly according to treatment (fruit size) at a distance of $1 \mathrm{~m}$ apart with 12 seedlings per plot giving a population of 10,000 plants per hectare.

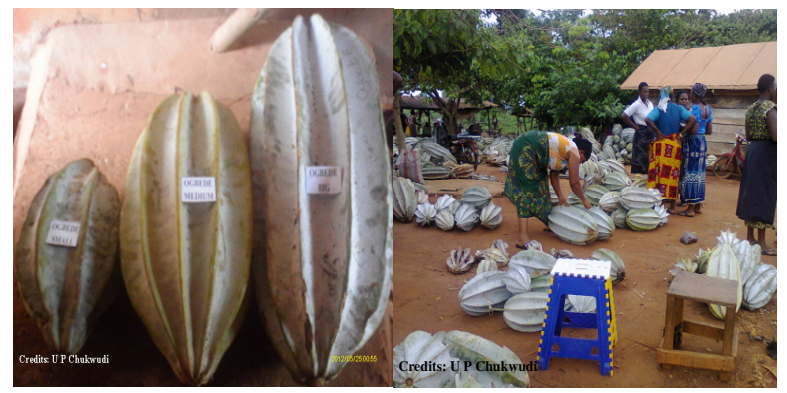

Fig. 1. Different Telfairia occidentalis fruit sizes on market place

Well cured pig manure was applied at $20 \mathrm{t} / \mathrm{ha}$ to the plots two weeks before transplanting and supplemented with inorganic fertilizer $(15: 15: 15)$ at $750 \mathrm{~kg} / \mathrm{ha}$ split at four and ten weeks after transplanting (WAT).

The following equations were used to calculate the parameters specified below:

Seedling Emergence Percentage:

$(\mathrm{SEP})=\frac{\text { Number of emerged seeds }}{\text { Number of planted seeds }} x 100$ Equation 1

Coefficient of velocity of germination (Nichols and Heydecker, 1968):

$$
\mathrm{CVG}=\left(\sum_{i}^{k} f_{i} / \sum_{i}^{k}={ }_{1} f_{i} x_{i}\right) 100 \quad \text { Equation } 2
$$

Where $f i$ : number of seeds newly germinating on day $i$

$x_{i}$ : number of days from sowing, and

$k:$ last day of germination.

Mean germination rate (MGR) (Labouriau, 1970):

$\bar{v}=\mathrm{CV} / 100=1 \sqrt{t}$

Equation 3
Where ${ }_{v}^{-}$: mean germination rate

$\bar{t}$ : mean germination time, and

$c v$ : coefficient of velocity.

Total number of seeds/fruit (TNS) and 10-seed weight (SWt.) were obtained from the fruits before planting, while length of the longest vine, number of leaves/plant, number of leaves/vine length of $40 \mathrm{~cm}$, length of the central leaflet, width of the central leaflet, vine diameter and marketable leaf yield by weight were measured in the field biweekly from the two middle row plants to avoid border effect. The border plants were harvested alongside the sample plants to avoid overshadowing of the sample plants. Number of fruits, weight, length and circumference of fruits were recorded at the end of the experiment from the whole population.

Variable costs recorded included cost of land preparation (ploughing, harrowing and bed making), weeding, purchase and transportation of fruits, manure and fertilizer.

Revenue accruing from the leaf and fruit yield sales was recorded using the average leaf price of 100 gram to N10 and fruit price of N650, N400 and N200 for large, medium and small sized fruit, respectively in the open market. Both the benefit-cost ratio and the gross margin (\%) were also calculated. The benefit-cost ratio and Gross margin were computed as:

Benefit Cost Ratio $(B C R)=\frac{\text { Revenue realized }}{\text { Total cost }} \quad$ Equation 4

Gross Margin (\%) $=\frac{\text { Total revenue }- \text { Total cost }}{\text { Total revenue }} x 100 \quad$ Equation 5

The vegetative measurement started four and three WAT in 2011 and 2012, respectively, while the leaf harvest begun eight and three WAT in 2011 and 2012, respectively.

\section{Statistical analysis}

The data collected were subjected to analysis of variance (ANOVA) using GenStat Release 10.3DE (2011) statistical software. The means were compared using Fisher's least significant difference (F-LSD) as described by Obi (2002). GGE (Genotype by Genotype x Environment interaction) biplot (6.3 Edition) software was used to show which-winwhere among the fruit sizes.

\section{Results}

Tab. 1 showed that the large sized fruits were significantly $(p<0.05)$ higher in total number of seeds and 10-seed weight than medium and small sized fruits. The medium sized fruits were significantly $(p<0.05)$ higher in seedling emergence than the small sized fruits, but statistically similar with large sized fruits. It also gave a significantly $(\mathrm{p}<0.05)$ higher $\mathrm{CVG}$ than the other fruit sizes.

Tab. 1. Effect of fruit size on seedling emergence of $T$. occidentalis

\begin{tabular}{lccccc}
\hline \multicolumn{1}{c}{ Fruit size } & TNS & SWt & SEP & CVG & MGR \\
\hline & & $(\mathrm{g})$ & $(\%)$ & & \\
Large & 97.58 & 155.6 & 80.53 & 7.33 & 0.07 \\
Medium & 83.44 & 139.3 & 83.20 & 7.74 & 0.08 \\
Small & 65.47 & 103.1 & 70.94 & 7.32 & 0.07 \\
F-LSD $(\mathrm{P}=0.05)$ & 1.34 & 4.1 & 7.22 & 0.30 & n.s \\
\hline
\end{tabular}

$\mathrm{TNS}=$ total number of seed $\mathrm{s} /$ fruit, $\mathrm{SWt}=10$ seed weight, $\mathrm{SEP}=$ seedling emergence percentage, $\mathrm{CVG}=$ cumulative velocity of germination, $\mathrm{MGR}=$ mean germination rate and $\mathrm{n} . \mathrm{s}=$ non-significant 
The large sized fruits gave a significantly $(\mathrm{p}<0.05)$ higher vine diameter of $6.31 \mathrm{~mm}$ at four WAT, but were statistically similar at six WAT with the medium sized fruits (Tab. 2). The medium sized fruits were significantly $(\mathrm{p}<0.05)$ higher in number of vines, width and length of the central leaflet than the small sized fruits at six WAT. It also gave a significantly $(\mathrm{p}<0.05)$ higher vine diameter than small sized fruits at ten WAT. Large sized fruits gave statistically similar number of leaves/plant with medium sized fruit at four WAT. At six WAT, medium sized fruits were significantly $(p<0.05)$ higher than the other fruit sizes in number of leaves/plant. Small sized fruits were significantly $(p<0.05)$ higher in number of leaves/vine length of $40 \mathrm{~cm}$ than the others at six and eight WAT. It produced the lowest values for all the other parameters measured over the different periods, except for number of leaves/plant at eight WAT.

Large and medium sized fruits were significantly $(\mathrm{p}<0.05)$ higher in leaf yield than small sized fruits at eight WAT and in total leaf yield/hectare in 2011 (Tab. 3). Medium sized fruits gave the highest leaf yield at ten, twelve and fourteen WAT. In 2012 cropping season, small sized fruits were significantly $(p<0.05)$ lower in leaf yield than large and medium sized fruits at three, five WAT and total leaf yield/hectare (Tab. 4). There was no significant $(\mathrm{P}=0.05)$ difference between large and medium sized fruits in marketable leaf yield in both years.

Medium sized fruits were significantly $(\mathrm{p}<0.05)$ higher in number of fruits/hectare, total fruit weight/hectare, average fruit weight and fruit circumference than small sized fruits in 2011 (Tab. 5). The large sized fruits were significantly $(p<0.05)$ higher in fruit length than medium and small fruit sizes. In 2012 cropping season, there was no significant $(p<0.05)$ difference for all the fruit parameters measured. However, medium sized fruits gave the highest value for fruit circumference, total number and weight of fruits/hectare, while large sized fruits gave the longest fruits.

Tab. 2. Effect of fruit size on morphological growth parameters of T. occidentalis over ten weeks after transplanting in 2011

\begin{tabular}{|c|c|c|c|c|c|c|c|}
\hline Fruit Size & VD & $\mathrm{NOV}$ & LLV & LP & LVL & WCL & $\mathrm{LCL}$ \\
\hline \multicolumn{8}{|c|}{$4 \mathrm{WAT}$} \\
\hline Large & 6.31 & 4.00 & 111.30 & 51.60 & 6.91 & 6.49 & 11.53 \\
\hline Medium & 5.97 & 4.11 & 110.50 & 47.20 & 6.56 & 7.06 & 12.74 \\
\hline Small & 5.11 & 3.78 & 78.70 & 39.80 & 7.20 & 5.80 & 10.82 \\
\hline $\mathrm{F}-\mathrm{LSD}(\mathrm{P}=0.05)$ & 0.33 & n.s & 12.44 & 5.92 & n.s & 0.36 & 0.59 \\
\hline \multicolumn{8}{|c|}{$6 \mathrm{WAT}$} \\
\hline Large & 7.64 & 7.49 & 159.20 & 89.00 & 5.52 & 6.88 & 12.43 \\
\hline Medium & 7.47 & 7.75 & 163.30 & 102.00 & 5.52 & 7.25 & 12.95 \\
\hline Small & 6.44 & 6.85 & 110.00 & 74.70 & 6.70 & 6.12 & 11.03 \\
\hline $\mathrm{F}-\mathrm{LSD}(\mathrm{P}=0.05)$ & 0.38 & 0.74 & 15.57 & 9.08 & 0.42 & 0.34 & 0.72 \\
\hline \multicolumn{8}{|c|}{8 WAT } \\
\hline Large & 9.67 & 4.28 & 240.90 & 179.20 & 4.08 & 7.20 & 12.55 \\
\hline Medium & 10.19 & 4.24 & 226.00 & 164.00 & 4.51 & 7.44 & 12.96 \\
\hline Small & 8.21 & 3.97 & 169.50 & 182.50 & 5.74 & 6.32 & 11.86 \\
\hline $\mathrm{F}-\mathrm{LSD}(\mathrm{P}=0.05)$ & 0.51 & n.s & 27.48 & n.s & 0.63 & 0.55 & 0.74 \\
\hline \multicolumn{8}{|c|}{$10 \mathrm{WAT}$} \\
\hline Large & 11.48 & 5.33 & & & & & \\
\hline Medium & 11.69 & 4.96 & & & & & \\
\hline Small & 10.59 & 4.67 & & & & & \\
\hline $\mathrm{F}-\mathrm{LSD}(\mathrm{P}=0.05)$ & 0.93 & n.s & & & & & \\
\hline
\end{tabular}

$\mathrm{VD}=\mathrm{Vine}$ diameter $(\mathrm{mm}), \mathrm{NOV}=$ Number of vines, $\mathrm{LLV}=\mathrm{Length}$ of the longest vine $(\mathrm{cm}), \mathrm{LP}=$ Number of leaves/plant, $\mathrm{LVL}=\mathrm{Number}$ of leaves $/$ vine length of $40 \mathrm{~cm}$, WCL $=$ Width of the central leaflet $(\mathrm{cm}), \mathrm{LCL}=$ Length of the central leaflet $(\mathrm{cm})$, n.s=non-significant and WAT $=$ Week after transplanting

Tab. 3. Effect of fruit size on marketable leaf yield ( $\mathrm{t} / \mathrm{ha})$ of $T$. occidentalis in 2011

\begin{tabular}{lccccc}
\hline \multicolumn{1}{c}{ Fruit Size } & 8 WAT & 10 WAT & 12 WAT & 14 WAT & TOTAL \\
\hline Large & 3.68 & 2.24 & 1.88 & 0.33 & 8.14 \\
Medium & 3.46 & 2.51 & 2.05 & 0.40 & 8.42 \\
Small & 2.56 & 1.9 & 1.85 & 0.36 & 6.67 \\
F-LSD $(\mathrm{P}=0.05)$ & 0.53 & 0.59 & n.s & n.s & 1.05 \\
\hline
\end{tabular}

n.s=non-significant and WAT $=$ week after transplanting

Tab. 4. Effect of fruit size on marketable leaf yield $(\mathrm{t} / \mathrm{ha})$ of $T$. occidentalis in 2012

\begin{tabular}{lccccc}
\hline \multicolumn{1}{c}{ Fruit Size } & 3 WAT & 5 WAT & 7 WAT & 9 WAT & TOTAL \\
\hline Large & 0.28 & 0.39 & 0.53 & 0.76 & 1.96 \\
Medium & 0.27 & 0.36 & 0.58 & 0.80 & 2.00 \\
Small & 0.13 & 0.26 & 0.45 & 0.83 & 1.67 \\
F-LSD $(\mathrm{P}=0.05)$ & 0.06 & 0.09 & 0.11 & n.s & 0.28 \\
\hline
\end{tabular}

n.s=non-significant and WAT $=$ weeks after transplanting
Tab. 5. Effect of fruit size on fruit yield of T. occidentalis

\begin{tabular}{lccccc}
\hline \multicolumn{1}{c}{ Fruit Size } & NFH & TFWH & AFW & FC & FL \\
\hline & & $(\mathrm{t} / \mathrm{ha})$ & $(\mathrm{kg})$ & $(\mathrm{cm})$ & $(\mathrm{cm})$ \\
\hline Large & 2708.0 & 6.3 & 2.1 & 51.9 & 35.8 \\
Medium & 3160.0 & 7.6 & 2.4 & 52.3 & 31.9 \\
Small & 1944.0 & 3.9 & 1.5 & 33.9 & 22.0 \\
FLSD $(\mathrm{P}=0.05)$ & 836.0 & 2.1 & 0.7 & 3.8 & 2.5 \\
& & & 2012 & & \\
Large & 5139.0 & 12.3 & 2.4 & 53.4 & 33.7 \\
Medium & 6667.0 & 16.9 & 2.6 & 55.2 & 31.7 \\
Small & 6458.0 & 16.1 & 2.6 & 54.7 & 33.0 \\
FLSD $(\mathrm{P}=0.05)$ & $\mathrm{n} . \mathrm{s}$ & $\mathrm{n} . \mathrm{s}$ & $\mathrm{n} . \mathrm{s}$ & $\mathrm{n} . \mathrm{s}$ & $\mathrm{n} . \mathrm{s}$ \\
\hline
\end{tabular}

$\mathrm{NFH}=$ Number of Fruits/Hectare, TFWH=Total Fruit Weight/Hectare $(\mathrm{t} / \mathrm{ha})$, $\mathrm{AFW}=$ Average Fruit Weight $(\mathrm{kg}), \mathrm{FC}=$ Fruit Circumference $(\mathrm{cm})$ and $\mathrm{FL}=$ Fruit
Length 
512

Tab. 6. Total Cost, total revenue, benefit/cost and gross margin in T. occidentalis production as affected by fruit size

\begin{tabular}{|c|c|c|c|c|c|c|c|c|}
\hline Fruit Size & $\begin{array}{l}\text { Total Cost } \\
\text { (A) }\end{array}$ & $\begin{array}{l}\text { Leaf Revenue } \\
\text { (A) }\end{array}$ & $\begin{array}{c}\text { Fruit } \\
\text { Revenue }(\mathbb{A})\end{array}$ & $\begin{array}{c}\text { Total } \\
\text { Revenue }(\mathbb{A})\end{array}$ & $\begin{array}{l}\text { \% Leaf } \\
\text { Revenue }\end{array}$ & $\begin{array}{l}\text { \% Fruit } \\
\text { Revenue }\end{array}$ & $\begin{array}{c}\text { Benefit Cost } \\
\text { Ratio }\end{array}$ & $\begin{array}{c}\text { Gross Margin } \\
(\%)\end{array}$ \\
\hline & & & & & 2011 & & & \\
\hline Large & 514983.0 & 137330.4 & 417037.0 & 554367.4 & 24.8 & 75.2 & 1.1 & 7.1 \\
\hline Medium & 497785.0 & 136734.8 & 465555.6 & 602290.4 & 22.7 & 77.3 & 1.2 & 17.4 \\
\hline \multirow[t]{2}{*}{ Small } & 482782.7 & 104788.1 & 298518.5 & 403306.7 & 26.0 & 74.0 & 0.8 & -19.7 \\
\hline & & & & & 2012 & & & \\
\hline Large & 520040.0 & 106096.2 & 862222.2 & 968318.4 & 11.0 & 89.0 & 1.9 & 46.3 \\
\hline Medium & 502845.0 & 106283.5 & 1182222.2 & 1288505.7 & 8.2 & 91.8 & 2.6 & 61.0 \\
\hline Small & 487844.0 & 98781.8 & 1057407.4 & 1156189.2 & 8.5 & 91.5 & 2.4 & 57.8 \\
\hline
\end{tabular}

$\%=$ percentage, $¥=$ Naira, $\$ 1=¥ 160$

The three vertices in the biplot polygon were occupied by each of the fruit sizes (Fig. 2). No trait fell in the small sized fruit section. Fruit length fell in the large sized fruit section, while number of fruits/hectare, total fruit weight/hectare, average fruit weight, fruit circumference and total leaf yield fell in the medium sized fruit section.

Tab. 6 showed that medium sized fruit gave the highest total revenue of $\$ 3,764.3(\mathrm{~N} 602,290.4 \mathrm{~K})$ and $\$ 8,053.2$ $(\mathrm{N} 1,288,505.7 \mathrm{~K})$ in 2011 and 2012 , respectively. Its percentage fruit revenue contribution to the total revenue was the highest in both years. T. occidentalis fruit sales contributed minimum of $74 \%$ and $89 \%$ to the total revenue in 2011 and 2012, respectively. The highest benefit cost ratio (BCR) of 1.2 and 2.6 in 2011 and 2012, respectively were obtained from medium sized fruits. Small sized fruits gave the lowest benefit cost ratio of 0.8 and negative gross margin of $19.7 \%$ in 2011 . The performance indicators studied gave higher values in 2012 than 2011 except in percentage leaf revenue.

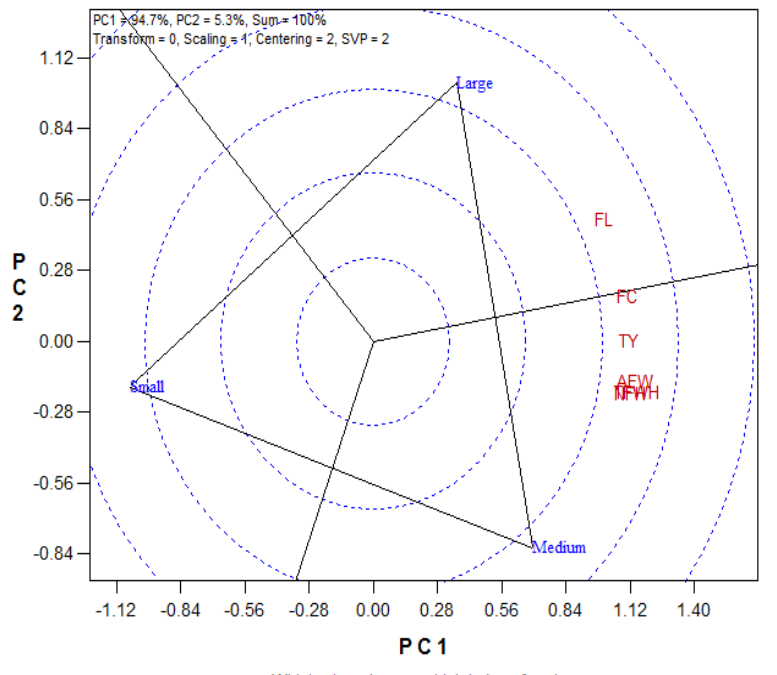

Fig. 2. The which-won-where view of the GGE biplot to show which fruit size performed best in which yield parameter

\section{Discussion}

The lower number of vines, vine length, number of leaves/plant, width and length of the central leaflet obtained from the small sized fruits at the early vegetative stage might be due to small food reserves in the seed that was instrumental in its slow field establishment and growth. The other fruit sizes gave higher 10-seed weight than the small sized fruits (Tab. 1). The result was in agreement with the study of Adeyemo and Odiaka (2004) that reported high individual seed weights in large fruits. Ugesse et al. (2008) associated heavy seed weight to better seedling performance in Shea butter (Vitellaria paradoxa Gaertn F.). Seed size, as a characteristic of seed quality, has been reported to influence seedling growth and establishment in crops (Nik et al., 2011). Amico et al. (1994) reported that higher vigour that occurred in larger seeds were due to the large food reserves in such seeds.

Seed size plays an important role in germination and establishment of vigorous seedlings that is essential to achieving high yield (Nik et al., 2011). The higher values obtained from small sized fruits in number of vines, number of leaves/plant, vine length, width and length of the central leaflet at late vegetative stage indicated slow rate of field establishment. Nerson (2002) showed that small muskmelon seeds had the lowest seedling growth which demonstrated that there is an association between seed physical parameters and seed quality.

Among the morphological parameters contributing to yield in T. occidentalis measured in the study, medium and large sized fruits were alternating in providing the highest value, excerpt in leaf size (length and width of the leaf) where the medium sized fruits gave the highest value through-out the evaluation periods. Aremu and Adewale (2012) had suggested breeding for increased leaf size in T. occidentalis. The relevance of leaf size in yield determination explains the higher performance of medium sized fruit in total marketable leaf yield in both years of evaluation. The lower yield obtained in 2012 was due to the early harvest of the plant in contrast to late harvest in 2011 when the number of branches had increased. Studies in wheat showed that seed size not only influence emergence and establishment, but also affected yield components and ultimately grain yield (Singh, 2003).

The medium sized fruits gave higher values in all the fruit parameters measured except in fruit length, where large sized fruits were higher than other sizes. This agreed with the findings of Mini et al. (2000) where large sized fruits gave higher fruit size than the other sizes in ash gourd (Benincasea hispida), a member of the Cucurbitaceae family.

The biplot explained $100 \%$ of the variation in the fruit sizes as predicted by Yan and Tinker (2006) for three accessions (genotypes) data set. The which-won-where biplot showed that large sized fruit were the best performer in fruit 
length, suggesting that fruit size might be affected more by genetic make up than environmental influence. The medium sized fruit performed better in total marketable leaf yield, average fruit weight, number of fruits/hectare, total fruit weight/hectare than the other fruit sizes. The clustering of some of the measured traits (AFW, TNF and TFWH) on the biplot is an indication that similar information were provided by them, therefore, selection of one of them could had provided the needed information. This implied that there is a relationship between fluted pumpkin fruit weight and fruit number harvested from the same plant. The biplot also showed that large and medium sized fruits performed similarly in fruit circumference. This may be due to genetic constituents of the fruit sizes, because it was consistent in both years. Fruit size had been identified as a potential trait for characterization of fluted pumpkin accessions (Odiaka et al., 2008).

From the result of this experiment, comparing 2011 and 2012 total revenue, it is evident that extending leaf harvest into flowering/fruiting phase of $T$. occidentalis reduces the fruit quality and quantity, as the harvested leaves reduce the photosynthetic ability of the plant to convert the photosynthates needed to fill the fruits. The termination of leaf harvest at the onset of fruiting in 2012 planting season resulted in higher total revenue, gross margin and general break even for all the fruit sizes than in 2011 planting season. The study showed that fruit sales contributed a high percentage of the total revenue in both years. Odiaka et al. (2008) had reported a fruit profit gain of $144 \%$ over leaf production in T. occidentalis.

Benefit-cost ratio is one of the criteria for determining the viability of a project. It compares the total benefits of a project with its total costs and recommends the implementation of the project if benefits exceed the costs. When the BCR is equal to or greater than unity (one) then the project is viable (Arene, 2008). And it also provides a score that is used by managers to prioritize projects for investment. The project with the highest score is ranked first (Pannell, 2012). The highest BCR of medium sized fruits indicates that it should be selected against the large and small size fruits. In 2011, the small sized fruits did not break even as it recorded a BCR of 0.8 that did not meet the required break even value of 1.0, which reflected in its negative gross margin. Higher gross margin entails greater efficiency in turning raw materials into income. The high gross margin percentage obtained in 2012 showed that commercial cultivation of $T$. occidentalis is a profitable enterprise as the producer will retain minimum of $\$ 0.3$ (N46.3) for each dollar (naira) of sales to service his/her other needs. This high profitability of $T$. occidentalis had earlier been reported by Odiaka et al. (2008) and Nwauwa and Omonona, (2010).

\section{Conclusions}

Fruit size had significant effect on the performance and profitability of $T$. occidentalis. Medium sized fruit was significantly higher in marketable leaf and fruit yield than the small sized fruit, but gave similar yield with large sized fruit. Fruit yield contributed more to the total revenue than leaf yield. Medium sized fruit is recommended in favour of small sized fruit for leaf and fruit production and higher economic returns.

\section{References}

Adeyemo MO, Odiaka NI (2004). Early seeding growth of fluted pumpkin as affected by seed and pod sizes under nursery and field conditions. Nigerian Journal of Horticultural Science 9:35-42

Ajayi SA, Berjak P, Kioko JI, Dulloo ME, Voduche RS (2006). Response of fluted pumpkin (Telfairia occidentalis Hook F., Cucurbitaceae) seeds to desiccation, chilling and hydrated storage. South African Journal of Botany 72(4):544-550.

Akanbi WB, Adebooye CO, Togun AO, Ogunrinde JO, Adeyeye SA (2007). Growth, herbage and seed yield and quality of Telfairia occidentalis as influenced by cassava peel compost and mineral fertilizer. World Journal of Agricultural Sciences 3(4):508-516.

Amico RU, Zizzo GV, Agnello S, Sciortino A, Iapichino G (1994). Effect of seed storage and seed size on germination, emergence and bulbelt production of Amaryllis belladonnal L. Acta Hortic (ISHS) 362:281-288.

Aregheore EM (2007). Voluntary intake, nutrient digestibility and nutritive value of foliage of fluted pumpkin (Telfairia occidentialis) - haylage mixtures by goats. Livestock Research for Rural Development 19(56) Retrieved 5/1/2012 from http://www.lrrd.org/lrrd19/4

Aremu CO, Adewale DB (2012). Origin and seed positional effect on sex ratio of Telfairia occidentalis Hook. F. grown in Savanna Agro-ecology. International Journal of Plant Breeding and Genetics 6:32-39.

Arene CJ (2008). Economic Analysis of Agricultural and Rural Development Projects: Planning, Appraisal, Implementation and Evaluation. Enugu: PRIZE publishers.

Asiegbu JE (1985). Influence of planting date on growth and productive life of fluted pumpkin Telfairia occidentalis Hook F. Tropical Agriculture 64(4):281-284.

Awodun MA (2007a). Effect of poultry manure on the growth, yield and nutrient content of fluted pumpkin (Telfaria occidentalis Hook F.). Asian Journal of Agricultural Research 1:67-73.

Awodun MA (2007b). Effect of tillage practices on the growth and yield of fluted pumpkin Telfaria occidentalis hook F). Proceedings African Crop Science Conference 8:463-465.

Chukwudi UP, Agbo CU (2013). Effect of trellis height and cutting frequency on leaf and fruit yield of fluted pumpkin (Telfairia occidentalis Hook F.) over two seasons in Nsukka. Proceedings Crop Science Society of Nigeria 1:348-357

Chukwudi UP, Agbo CU (2014a). Influence of fruit characteristics on seeds and seedling emergence of fluted pumpkin (Telfairia occidentalis Hook F.).J Anim Plant Sci 24(2):600-605.

Egun AC (2007). Comparative marketable leaf yield of staked and unstaked pumpkin (Telfairia occidentalis) in a tropical utisols. Stud. Home Comm Sci 1(1):27-29. 
514

GenStat Release 10.3DE (2011) VSN International Ltd. (Rothamsted Experimental Station).

Kayode AAA, Kayode OT (2011). Some medicinal values of Telfairia occidentalis: A Review Am J Biochem Mol Biol $1(1): 30-38$.

Labouriau LG (1970). On the physiology of seed germination in Vicia graminea Sm. I. Anais da Academia Brasileira de Ciências 42:235-262.

Mini P, Meagle JP, Rajan S (2000). Effect of fruit size on seed quality of Ashgourd. Seed Res 28(2): 215-216.

Nerson H (2002). Relationship between plant density and fruit and seed production in muskmelon. J Am Soc Hortic Sci 127(5):855-859.

Nichols MA, Heydecker W (1968). Two approaches to the study of germination data. Proceedings International Seed Testing Association 33:531-540.

Nik MM, Babaeian M, Tavassoli A (2011). Effect of seed size and genotype on germination characteristic and seed nutrient content of wheat. Scientific Research and Essays 6(9):2019-2025.

Nkang A, Omokoro D, Egbe A (2000). Effects of desiccation on the lipid peroxidation and activities of peroxide and polyphenoloxidase in seeds of Telfairia occidentalis. Seed Science and Technology 28(1):1-9.

Nwauwa LOE, Omonona BT (2010). Efficiency of vegetable production under irrigation system in Ilorin metropolis: A case study of fluted pumpkin (Telferia occidentalis). Continental J Agricultural Economics 4:9-18.
Obi IU (2002). Statistical methods of detecting difference between treatment means for field and laboratory experiments. AP Publishers Co Nig Ltd, Enugu, 117p.

Odiaka NI, Akoroda MO, Odiaka EC (2008). Diversity and production methods of fluted pumpkin (Telfairia occidentalis Hook F.): Experience with vegetable farmers in Makurdi, Nigeria. Afr J Biotechnol 7(8):944-954.

Ogar EA, Asiegbu JE (2005). Effect of fertilizer rates and cutting frequency on the marketable vegetable and fruit yields of in fluted pumpkin in Southern Nigeria. Agroscience 4(1):66-69.

Ogbonna PE (2008). Fruit portion and type effects on sex growth and yield in fluted pumpkin. African Crop Science Journal 16:185-190.

Pannell D (2012). The Benefit: Cost ratio. Investment framework for environmental resources version 19 Retrieved from www.inffer.org.

Singh ND (2003). Seed size and adventitious (nodal) roots as factors influencing the tolerance of wheat to water logging, Australian J. Agric. Res. 54:969-977.

Ugese FD, Baiyeri KP, Mbah BN (2008). Effect of seed source and watering intervals on growth and dry matter yield of shea butter tree (Vitellaria paradoxa Gaertn F.) seedlings. Bio-Research 6(1):303-307.

Yan W, Tinker NA (2006). Biplot analysis of multienvironment trial data: Principles and applications. Can J Plant Sci 86:623-645. 